\title{
Research on copper recovery from sledge from suspended copper concentrate reduction process
}

\author{
Badania nad odzyskiem miedzi z żużla \\ z zawiesinowego procesu redukcji koncentratów miedziowych
}

\begin{abstract}
The research on the dispersal of slag from the slurry process was carried out in a laboratory resistance furnace. Before declaring, the slag contained $13.62 \%$ copper. In the processes of reduction of slag samples with calcium carbide in the form of carbide with activating additives $\mathrm{Na}_{2} \mathrm{CO}_{3}$ and $\mathrm{CaF}_{2}$, the content of copper in the slag was reduced to a level of $0.28-0.63 \% \mathrm{Cu}$. The polymetallic melt formed after the decoupling of the slag contained $78.55-84.9 \% \mathrm{Cu}, 10.8-16.48 \% \mathrm{~Pb}$, and $0.08-0.39 \%$ Fe.
\end{abstract}

Keywords: slag, copper recovery, chemical composition

\section{Streszczenie}

Badania nad odmiedziowaniem żużla z procesu zawiesinowego przeprowadzono w oporowym piecu laboratoryjnym. Przed odmiedziowaniem żużel zawierał $13,62 \%$ miedzi. W procesach redukcji próbek żużla węglikiem wapnia w postaci karbidu z dodatkami aktywizującymi $\mathrm{Na}_{2} \mathrm{CO}_{3}$ i $\mathrm{CaF}_{2}$ osiągnięto obniżenie zawartości miedzi w żużlu do poziomu 0,28-0,63\% Cu. Powstający po odmiedziowaniu żużla stop polimetaliczny zawierał $78,55-84,9 \% \mathrm{Cu}, 10,8-16,48 \% \mathrm{~Pb}$ i $0,08-0,39 \%$ Fe.

Słowa kluczowe: żużel, odzyskiwanie miedzi, skład chemiczny

\section{Introduction}

The suspended copper reduction process from an ore concentrate is a significant advance in copper metallurgy compared to the shaft process. This process does not require briquetting of the ore concentrate nor the use of coke. It is more efficient and economical [1]. An important disadvantage of this process, however, is the high proportion of copper in the slag after the process. The share of copper in the slag can reach a level of several percentage points [1], which makes it necessary to switch off the slag in the

Remigiusz Romankiewicz, Ferdynand Romankiewicz: University of Zielona Góra, Faculty of Mechanical Engineering, Zielona Góra, Poland; r.romankiewicz@ibem.uz.zgora.pl 
process carried out in an electric resistance furnace. T. Karwan [2] and others [1] believe that some copper in a slurry slag is in metallic form, but the main copper content is in the form of $\mathrm{Cu}_{2} \mathrm{O}$. This results in the desirability of conducting research to improve the effectiveness of slagging.

The previous author's studies [3] and other publications [4-6] show that the active reductor of cuprous oxide is calcium carbide; however, this has a high melting and dissociation temperature. The reduced melting temperature shows a technical carbide containing $75 \%$ calcium carbide and $22 \%$ calcium oxide. The reduction of cuprous oxide with calcium carbide proceeds according to the following reaction:

$$
4 \mathrm{Cu}_{2} \mathrm{O}+\mathrm{CaC}_{2}=8 \mathrm{Cu}+\mathrm{CaO}+\mathrm{CO}_{2}+\mathrm{CO}
$$

The stoichiometry of Reaction (1) shows that calcium carbide is a very effective reducer, because it reduces an eight-times-greater mass of $\mathrm{Cu}_{2} \mathrm{O}$ as related to its own $\left(\mathrm{CaC}_{2}\right)$. The emitted finished reaction products cause the mixing of reagents, which intensifies the process of reduction. Studies [3-6] have shown that the dissociation of calcium carbide activates compounds such as $\mathrm{Na}_{2} \mathrm{CO}_{3}, \mathrm{Na}_{2} \mathrm{~B}_{4} \mathrm{O}_{7}, \mathrm{~B}_{2} \mathrm{O}_{3}, \mathrm{NaF}$, and $\mathrm{CaF}_{2}$. $\mathrm{CaF}_{2}$ was added to facilitate the dissociation of $\mathrm{CaC}_{2}$ as well as to reduce the viscosity of the slag, which should facilitate the sedimentation of fine droplets of metallic copper from the slag to the polymetallic alloy.

\section{Description of research}

The research on the dispersal of slag from the slurry process was carried out in a laboratory resistance furnace. The chemical composition of the slag being tested is presented in Table 1. The chemical analysis of the slag was carried out using a Philips Spectrometer (Type PW 1600).

Table 1. Chemical composition of slag

\begin{tabular}{|c|c|c|c|c|c|c|c|c|}
\hline Component & $\mathrm{Cu}$ & $\mathrm{Fe}$ & $\mathrm{Pb}$ & $\mathrm{Zn}$ & $\mathrm{SiO}_{2}$ & $\mathrm{CaO}$ & $\mathrm{Al}_{2} \mathrm{O}_{3}$ & $\mathrm{MgO}$ \\
\hline wt. $\%$ & 13.62 & 4.58 & 3.42 & 0.75 & 33.17 & 13.14 & 11.47 & 10.51 \\
\hline
\end{tabular}

For the removal of copper from the slag, reduction mixtures based on technical carbide with $75 \%$ calcium carbide $\mathrm{CaC}_{2}$ and $22 \% \mathrm{CaO}$ were prepared.

As chemicals activating the reduction process contained in the carbide with calcium carbide, sodium $\mathrm{Na}_{2} \mathrm{CO}_{3}$ and $\mathrm{CaF}_{2}$ fluorite were selected. It was considered that the gas phase resulting from the decomposition of these compounds would cause intense mixing of the liquid slag, which should simplify the contact of the reducer with the copper oxide, lead, iron, and other metal oxides (as well as the sulfides). The sodium oxide $\left(\mathrm{Na}_{2} \mathrm{O}\right)$ produced from the decomposition of $\mathrm{Na}_{2} \mathrm{CO}_{3}$ will significantly reduce the viscosity of the 
slag, which will facilitate the coagulation of metallic particles of copper and lead inclusions and their sedimentation to the polymetallic alloy. Taking into account the composition of the reducing mixtures and the amount of the blends used in relation to the slag mass, the test program is shown in Table 2. The $\mathrm{CaF}_{2}$ addition was limited to $5 \%$ in the reducing mixture to avoid the release of an excessive amount of fluorine gas.

Table 2. Research program

\begin{tabular}{|c|c|c|c|c|}
\hline \multirow{2}{*}{$\begin{array}{c}\text { Series } \\
\text { of tests }\end{array}$} & \multicolumn{2}{|c|}{ Chemical composition of reducing compound [wt. \%] } & $\begin{array}{c}\text { Addition of reducing } \\
\text { mixture based on slag mass [\%] }\end{array}$ \\
\cline { 2 - 4 } & Carbide & $\mathbf{N a}_{\mathbf{2}} \mathbf{C O}_{\mathbf{3}}$ & $\mathbf{C a F}_{\mathbf{2}}$ & 2 \\
\hline 1 & 87 & 8 & 5 & 2.5 \\
\hline 2 & 87 & 8 & 5 & 4 \\
\hline 3 & 87 & 8 & 5 & 2 \\
\hline 4 & 80 & 15 & 5 & 2.5 \\
\hline 5 & 80 & 15 & 5 & 4 \\
\hline 6 & 80 & 15 & 5 & \\
\hline
\end{tabular}

The reducing compound was added to the slag after melting in an alundum crucible and overheating it to a temperature of $1300^{\circ} \mathrm{C}$. During the removal of copper from the slag suspension, ten-fold slag samples were taken at the time intervals given in Tables 3-8 and corresponding Figures $1-6$. The tables contain the results of the chemical analysis of the slag samples that were taken.

The results of the chemical analysis of the polymetallic alloy being the product of the slagging process are given in Table 9. The microstructure of the samples from the individual series of slagging is illustrated in Figures $7-12$.

Table 3. Results of chemical analysis of slag samples taken in Series of Tests No. 1

\begin{tabular}{|c|c|c|c|c|c|c|c|c|c|c|}
\hline \multirow{2}{*}{$\begin{array}{c}\text { No. of } \\
\text { sample }\end{array}$} & \multicolumn{2}{|c|}{$\begin{array}{c}\text { Time to take sample } \\
\text { from moment of }\end{array}$} & \multicolumn{7}{|c|}{ Slag composition [wt. \%] } \\
\cline { 2 - 12 } & $\begin{array}{c}\text { turning on } \\
\text { furnace [s] }\end{array}$ & $\begin{array}{c}\text { introducing } \\
\text { reducer [s] }\end{array}$ & $\mathbf{C u}$ & $\mathbf{F e}$ & $\mathbf{P b}$ & $\mathbf{Z n}$ & $\mathbf{S i O}_{\mathbf{2}}$ & $\mathbf{M g O}$ & $\mathbf{C a O}$ & $\mathbf{A l}_{\mathbf{2}} \mathbf{O}_{\mathbf{3}}$ \\
\hline 1 & 2100 & 300 & 6.58 & 5.20 & 2.40 & 0.73 & 35.48 & 10.67 & 17.74 & 11.27 \\
\hline 2 & 3000 & 1200 & 3.07 & 5.74 & 2.17 & 0.79 & 37.27 & 11.03 & 17.25 & 11.67 \\
\hline 3 & 3900 & 2100 & 4.30 & 5.76 & 2.16 & 0.80 & 37.23 & 10.92 & 17.15 & 11.64 \\
\hline 4 & 4800 & 3000 & 2.24 & 5.94 & 1.81 & 0.78 & 38.96 & 11.10 & 18.64 & 11.95 \\
\hline 5 & 5700 & 3900 & 1.78 & 5.95 & 1.72 & 0.80 & 39.22 & 11.35 & 18.10 & 12.48 \\
\hline 6 & 7500 & 5700 & 1.85 & 6.05 & 1.51 & 0.76 & 40.84 & 11.19 & 17.21 & 12.50 \\
\hline 7 & 9500 & 7500 & 1.38 & 6.05 & 1.32 & 0.75 & 40.25 & 11.24 & 17.73 & 12.81 \\
\hline 8 & 11,100 & 9300 & 1.04 & 6.05 & 1.26 & 0.75 & 40.03 & 11.16 & 17.25 & 13.24 \\
\hline 9 & 12,900 & 11,100 & 1.04 & 6.05 & 1.15 & 0.74 & 40.15 & 11.20 & 17.75 & 13.10 \\
\hline 10 & 16,500 & 14,700 & 0.74 & 6.09 & 1.13 & 0.72 & 39.88 & 11.29 & 17.95 & 13.06 \\
\hline
\end{tabular}




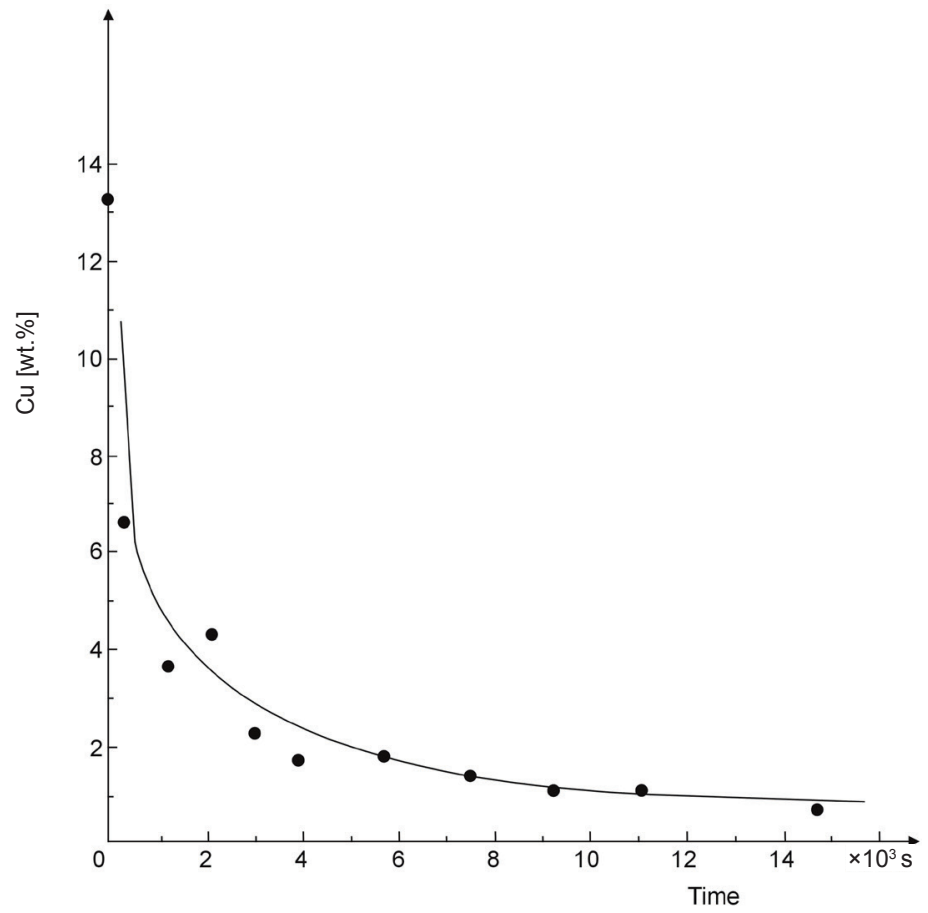

Fig. 1. Dependence of copper content change in slag since time when reduction process was carried out (Series of Tests No. 1)

Table 4. Results of chemical analysis of samples taken in Series of Tests No. 2

\begin{tabular}{|c|c|c|c|c|c|c|c|c|c|c|}
\hline \multirow{2}{*}{$\begin{array}{c}\text { No. of } \\
\text { sample }\end{array}$} & \multicolumn{2}{|c|}{$\begin{array}{c}\text { Time to take sample } \\
\text { from moment of }\end{array}$} & \multicolumn{7}{|c|}{ Slag composition [wt. \%] } \\
\cline { 2 - 13 } & $\begin{array}{c}\text { turning on } \\
\text { furnace [s] }\end{array}$ & $\begin{array}{c}\text { introducing } \\
\text { reducer [s] }\end{array}$ & $\mathbf{C u}$ & $\mathrm{Fe}$ & $\mathbf{P b}$ & $\mathbf{Z n}$ & SiO $_{2}$ & MgO & CaO $_{|c|}$ & $\mathbf{A l}_{2} \mathbf{O}_{3}$ \\
\hline 1 & 1800 & 300 & 7.74 & 5.58 & 2.73 & 0.75 & 33.31 & 11.07 & 13.96 & 12.23 \\
\hline 2 & 2700 & 1200 & 2.87 & 5.61 & 1.60 & 0.62 & 35.66 & 11.23 & 18.18 & 13.11 \\
\hline 3 & 3600 & 2100 & 1.68 & 5.54 & 1.02 & 0.48 & 37.78 & 11.57 & 18.66 & 13.62 \\
\hline 4 & 4500 & 3000 & 1.03 & 5.20 & 0.96 & 0.46 & 38.24 & 11.69 & 18.27 & 13.70 \\
\hline 5 & 5400 & 3900 & 1.14 & 5.34 & 0.75 & 0.40 & 38.63 & 11.77 & 19.38 & 13.93 \\
\hline 6 & 7200 & 5700 & 1.53 & 5.51 & 1.42 & 0.69 & 38.77 & 10.95 & 17.95 & 12.20 \\
\hline 7 & 9000 & 7500 & 1.23 & 5.62 & 1.21 & 0.69 & 31.02 & 9.17 & 17.50 & 10.09 \\
\hline 8 & 10,800 & 9300 & 0.89 & 5.56 & 1.19 & 0.73 & 35.49 & 7.84 & 14.48 & 8.04 \\
\hline 9 & 12,600 & 11,100 & 1.12 & 5.59 & 1.00 & 0.68 & 37.68 & 10.73 & 17.73 & 12.47 \\
\hline 10 & 16,200 & 14,700 & 0.70 & 5.61 & 0.93 & 0.70 & 38.81 & 10.93 & 18.61 & 13.03 \\
\hline
\end{tabular}




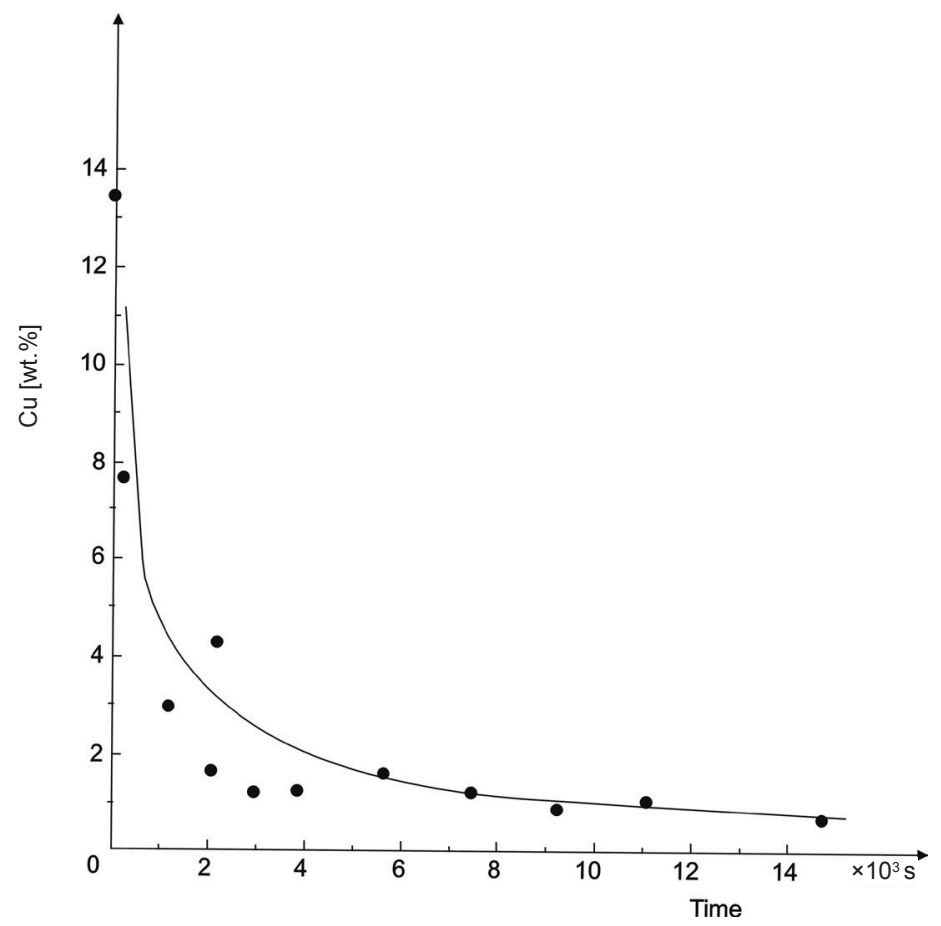

Fig. 2. Dependence of copper content change in slag since time when reduction process was carried out (Series of Tests No. 2)

Table 5. Results of chemical analysis of samples taken in Series of Tests No. 3

\begin{tabular}{|c|c|c|c|c|c|c|c|c|c|c|}
\hline \multirow{2}{*}{$\begin{array}{c}\text { No. of } \\
\text { sample }\end{array}$} & \multicolumn{2}{|c|}{$\begin{array}{c}\text { Time to take sample } \\
\text { from moment of }\end{array}$} & \multicolumn{7}{|c|}{ Slag composition [wt. \%] } \\
\cline { 2 - 12 } & $\begin{array}{c}\text { turning on } \\
\text { furnace [s] }\end{array}$ & $\begin{array}{c}\text { introducing } \\
\text { reducer [s] }\end{array}$ & $\mathbf{C u}$ & $\mathbf{F e}$ & $\mathbf{P b}$ & $\mathbf{Z n}$ & $\mathbf{S i O}_{2}$ & $\mathbf{M g O}$ & $\mathbf{C a O}^{\prime}$ & $\mathbf{A l}_{2} \mathbf{O}_{3}$ \\
\hline 1 & 1800 & 300 & 11.12 & 5.15 & 2.74 & 0.76 & 32.15 & 10.47 & 13.00 & 10.43 \\
\hline 2 & 2700 & 1200 & 2.16 & 5.70 & 1.85 & 0.72 & 38.45 & 11.18 & 18.50 & 12.09 \\
\hline 3 & 3600 & 2100 & 1.78 & 5.79 & 1.62 & 0.72 & 39.18 & 11.74 & 18.98 & 12.42 \\
\hline 4 & 4500 & 3000 & 1.41 & 5.84 & 1.53 & 0.70 & 38.96 & 11.05 & 19.06 & 12.27 \\
\hline 5 & 5400 & 3900 & 2.59 & 5.81 & 1.74 & 0.66 & 39.35 & 10.09 & 19.76 & 11.75 \\
\hline 6 & 7200 & 5700 & 1.57 & 5.87 & 1.43 & 0.67 & 39.16 & 10.93 & 18.78 & 12.22 \\
\hline 7 & 9000 & 7500 & 1.39 & 5.81 & 1.17 & 0.66 & 39.13 & 10.74 & 19.98 & 12.22 \\
\hline 8 & 10,800 & 9300 & 1.17 & 5.93 & 1.07 & 0.69 & 40.14 & 11.01 & 18.02 & 12.48 \\
\hline 9 & 12,600 & 11,100 & 1.19 & 5.85 & 0.99 & 0.70 & 39.30 & 11.01 & 19.09 & 12.93 \\
\hline 10 & 16,200 & 14,700 & 0.63 & 5.87 & 0.89 & 0.69 & 39.44 & 11.04 & 19.03 & 13.23 \\
\hline
\end{tabular}




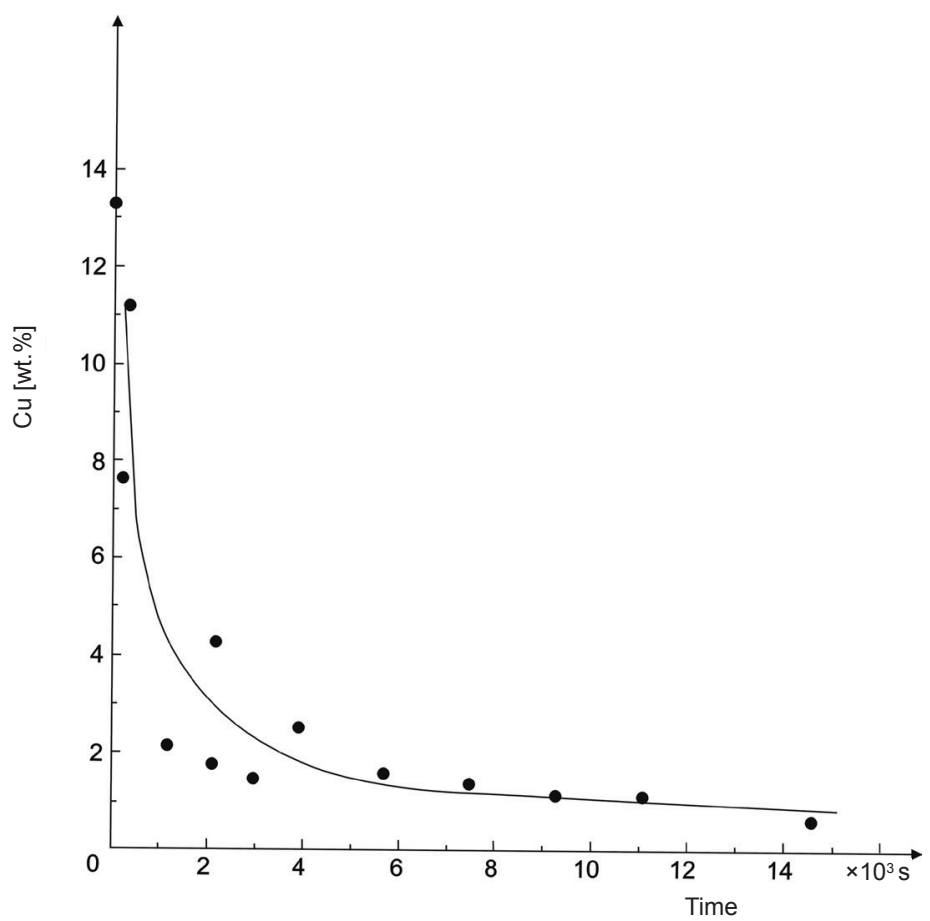

Fig. 3. Dependence of copper content change in slag since time when reduction process was carried out (Series of Tests No. 3)

Table 6. Results of chemical analysis of samples taken in Series of Tests No. 4

\begin{tabular}{|c|c|c|c|c|c|c|c|c|c|c|}
\hline \multirow{2}{*}{$\begin{array}{l}\text { No. of } \\
\text { sample }\end{array}$} & \multicolumn{2}{|c|}{$\begin{array}{l}\text { Time to take sample } \\
\text { from moment of }\end{array}$} & \multicolumn{8}{|c|}{ Slag composition [wt. \%] } \\
\hline & $\begin{array}{l}\text { turning on } \\
\text { furnace [s] }\end{array}$ & $\begin{array}{l}\text { introducing } \\
\text { reducer [s] }\end{array}$ & $\mathrm{Cu}$ & $\mathrm{Fe}$ & $\mathbf{P b}$ & Zn & $\mathrm{SiO}_{2}$ & MgO & $\mathrm{CaO}$ & $\mathrm{Al}_{2} \mathrm{O}_{3}$ \\
\hline 1 & 2100 & 300 & 5.20 & 5.70 & 2.41 & 0.73 & 35.87 & 11.07 & 14.76 & 11.57 \\
\hline 2 & 3000 & 1200 & 2.49 & 5.75 & 1.88 & 0.78 & 37.83 & 11.15 & 17.42 & 11.72 \\
\hline 3 & 3900 & 2100 & 2.04 & 5.57 & 2.01 & 0.75 & 30.58 & 11.23 & 18.16 & 12.05 \\
\hline 4 & 4800 & 3000 & 1.17 & 5.99 & 1.40 & 0.75 & 39.44 & 11.34 & 18.32 & 12.31 \\
\hline 5 & 5700 & 3900 & 0.80 & 5.74 & 1.14 & 0.72 & 40.36 & 11.49 & 18.60 & 12.55 \\
\hline 6 & 7500 & 5700 & 0.87 & 6.04 & 0.92 & 0.65 & 40.33 & 11.34 & 18.44 & 12.55 \\
\hline 7 & 9300 & 7500 & 0.50 & 5.66 & 0.76 & 0.62 & 40.51 & 11.41 & 18.38 & 12.86 \\
\hline 8 & 11,100 & 9300 & 0.71 & 5.97 & 0.63 & 0.59 & 40.92 & 11.36 & 18.20 & 13.06 \\
\hline 9 & 12,900 & 11,100 & 0.56 & 5.63 & 0.65 & 0.56 & 40.88 & 11.39 & 17.97 & 13.14 \\
\hline 10 & 16,500 & 14,700 & 0.28 & 6.12 & 0.46 & 0.52 & 41.55 & 11.42 & 18.06 & 13.41 \\
\hline
\end{tabular}




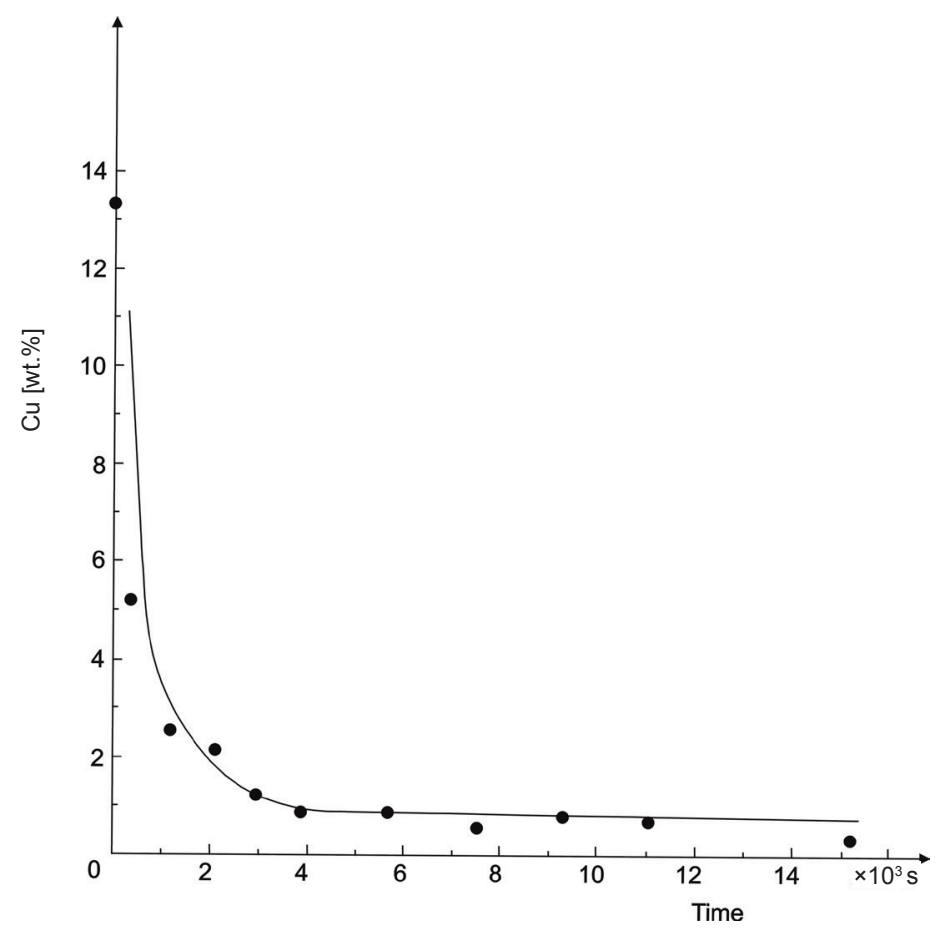

Fig. 4. Dependence of copper content change in slag since time when reduction process was carried out (Series of Tests No. 4).

Table 7. Results of chemical analysis of samples taken in Series of Tests No. 5

\begin{tabular}{|c|c|c|c|c|c|c|c|c|c|c|}
\hline \multirow{2}{*}{$\begin{array}{c}\text { No. of } \\
\text { sample }\end{array}$} & \multicolumn{2}{|c|}{$\begin{array}{c}\text { Time to take sample } \\
\text { from moment of }\end{array}$} & \multicolumn{7}{|c|}{ Slag composition [wt. \%] } \\
\cline { 2 - 12 } & $\begin{array}{c}\text { turning on } \\
\text { furnace [s] }\end{array}$ & $\begin{array}{c}\text { introducing } \\
\text { reducer [s] }\end{array}$ & $\mathbf{C u}$ & $\mathbf{F e}$ & $\mathbf{P b}$ & $\mathbf{Z n}$ & $\mathbf{S i O}_{2}$ & $\mathbf{M g O}$ & $\mathbf{C a O}^{\prime}$ & $\mathbf{A l}_{2} \mathbf{O}_{3}$ \\
\hline 1 & 2100 & 300 & 6.20 & 5.55 & 2.54 & 0.80 & 34.87 & 10.87 & 14.22 & 11.04 \\
\hline 2 & 3000 & 1200 & 3.65 & 5.26 & 2.24 & 0.80 & 36.79 & 10.75 & 18.26 & 11.23 \\
\hline 3 & 3900 & 2100 & 1.93 & 5.75 & 1.83 & 0.77 & 38.12 & 10.92 & 18.92 & 11.76 \\
\hline 4 & 4100 & 3000 & 1.80 & 5.34 & 1.54 & 0.75 & 37.51 & 10.75 & 19.17 & 11.58 \\
\hline 5 & 5700 & 3900 & 0.56 & 5.83 & 0.94 & 0.74 & 39.38 & 11.09 & 19.26 & 12.06 \\
\hline 6 & 7500 & 5700 & 0.83 & 5.54 & 0.84 & 0.70 & 39.66 & 11.04 & 18.73 & 12.49 \\
\hline 7 & 9300 & 7500 & 0.44 & 5.82 & 0.66 & 0.66 & 40.00 & 11.02 & 18.77 & 12.49 \\
\hline 8 & 11,100 & 9300 & 0.72 & 5.56 & 0.56 & 0.64 & 40.96 & 11.03 & 18.77 & 12.77 \\
\hline 9 & 12,900 & 11,100 & 0.37 & 5.87 & 0.47 & 0.61 & 40.90 & 11.14 & 18.52 & 13.15 \\
\hline 10 & 16,500 & 14,700 & 0.27 & 6.03 & 0.38 & 0.56 & 41.04 & 11.13 & 18.32 & 13.47 \\
\hline
\end{tabular}




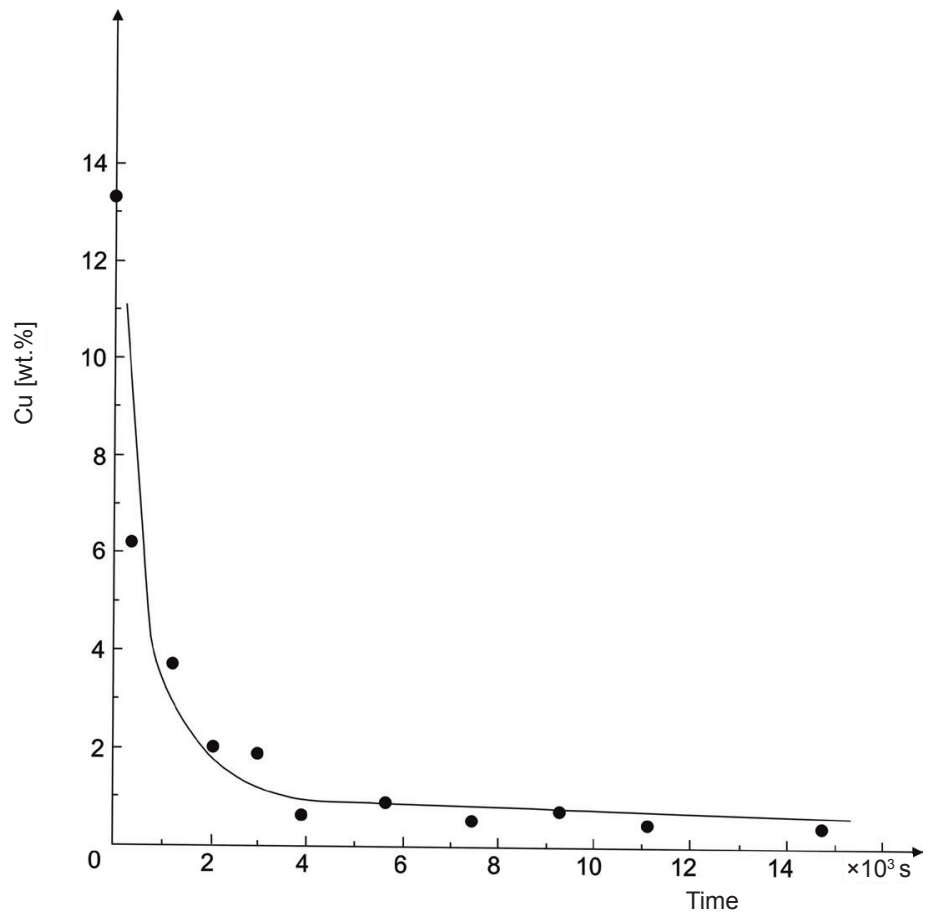

Fig. 5. Dependence of copper content change in slag since time when reduction process was carried out (Series of Tests No. 5)

Table 8. Results of chemical analysis of samples taken in Series of Tests No. 6

\begin{tabular}{|c|c|c|c|c|c|c|c|c|c|c|}
\hline \multirow{2}{*}{$\begin{array}{l}\text { No. of } \\
\text { sample }\end{array}$} & \multicolumn{2}{|c|}{$\begin{array}{l}\text { Time to take sample } \\
\text { from moment of }\end{array}$} & \multicolumn{8}{|c|}{ Slag composition [wt. \%] } \\
\hline & $\begin{array}{l}\text { turning on } \\
\text { furnace }[s]\end{array}$ & $\begin{array}{l}\text { introducing } \\
\text { reducer [s] }\end{array}$ & $\mathrm{Cu}$ & $\mathrm{Fe}$ & $\mathbf{P b}$ & $\mathrm{Zn}$ & $\mathrm{SiO}_{2}$ & MgO & $\mathrm{CaO}$ & $\mathrm{Al}_{2} \mathrm{O}_{3}$ \\
\hline 1 & 1800 & 300 & 8.67 & 5.06 & 2.74 & 0.78 & 34.10 & 10.45 & 13.37 & 10.99 \\
\hline 2 & 2700 & 1200 & 477 & 4.58 & 2.23 & 0.66 & 32.32 & 9.19 & 20.40 & 9.70 \\
\hline 3 & 3600 & 2100 & 1.39 & 4.72 & 0.63 & 0.48 & 38.37 & 10.41 & 23.05 & 11.03 \\
\hline 4 & 4500 & 3000 & 1.14 & 4.49 & 0.54 & 0.42 & 38.38 & 10.12 & 22.76 & 11.18 \\
\hline 5 & 5400 & 3900 & 0.84 & 4.63 & 0.34 & 0.40 & 39.11 & 10.31 & 22.71 & 11.47 \\
\hline 6 & 7200 & 5700 & 0.74 & 4.05 & 0.24 & 0.26 & 37.80 & 9.98 & 22.08 & 11.20 \\
\hline 7 & 9000 & 7500 & 0.46 & 3.71 & 0.09 & 0.19 & 39.77 & 10.17 & 23.69 & 11.69 \\
\hline 8 & 10,800 & 9300 & 0.33 & 3.61 & 0.13 & 0.18 & 39.42 & 10.08 & 23.04 & 12.19 \\
\hline 9 & 12,600 & 11,100 & 0.65 & 3.67 & 0.13 & 0.18 & 39.53 & 10.07 & 23.04 & 12.19 \\
\hline 10 & 16,200 & 14,700 & 0.35 & 3.78 & 0.15 & 0.17 & 39.61 & 10.11 & 22.63 & 12.53 \\
\hline
\end{tabular}




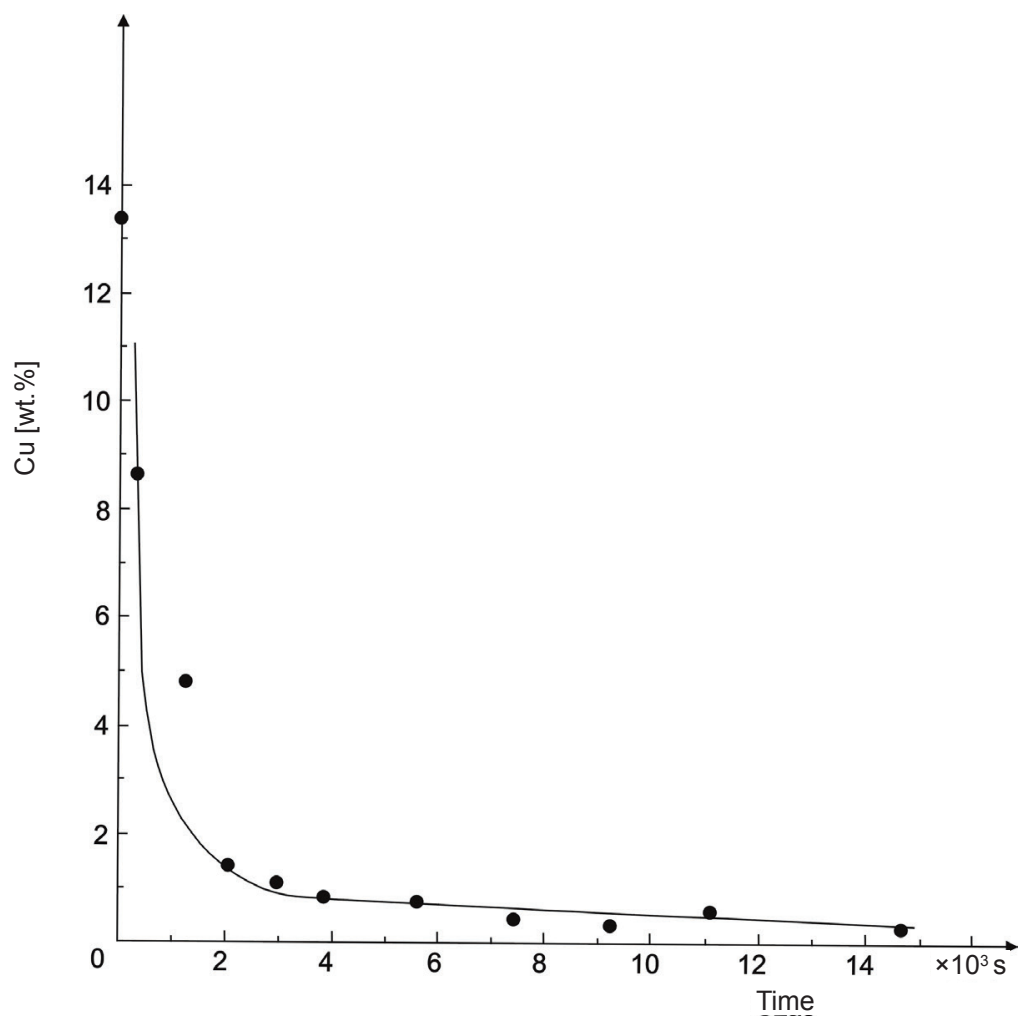

Fig. 6. Dependence of copper content change in slag since time when reduction process was carried out (Series of Tests No. 6)

Table 9. Chemical composition of polymetallic alloy [wt.\%]

\begin{tabular}{|c|c|c|c|c|c|c|}
\hline \multirow{2}{*}{ Element } & \multicolumn{7}{|c|}{ No. series of tests } \\
\cline { 2 - 7 } & $\mathbf{1}$ & $\mathbf{2}$ & $\mathbf{3}$ & $\mathbf{4}$ & $\mathbf{5}$ & $\mathbf{6}$ \\
\hline $\mathrm{Cu}$ & 84.94 & 83.19 & 82.91 & 81.82 & 79.97 & 78.55 \\
\hline $\mathrm{Pb}$ & 10.80 & 11.81 & 12.11 & 13.29 & 14.21 & 16.48 \\
\hline $\mathrm{Fe}$ & 0.08 & 0.09 & 0.09 & 0.10 & 0.15 & 0.39 \\
\hline
\end{tabular}




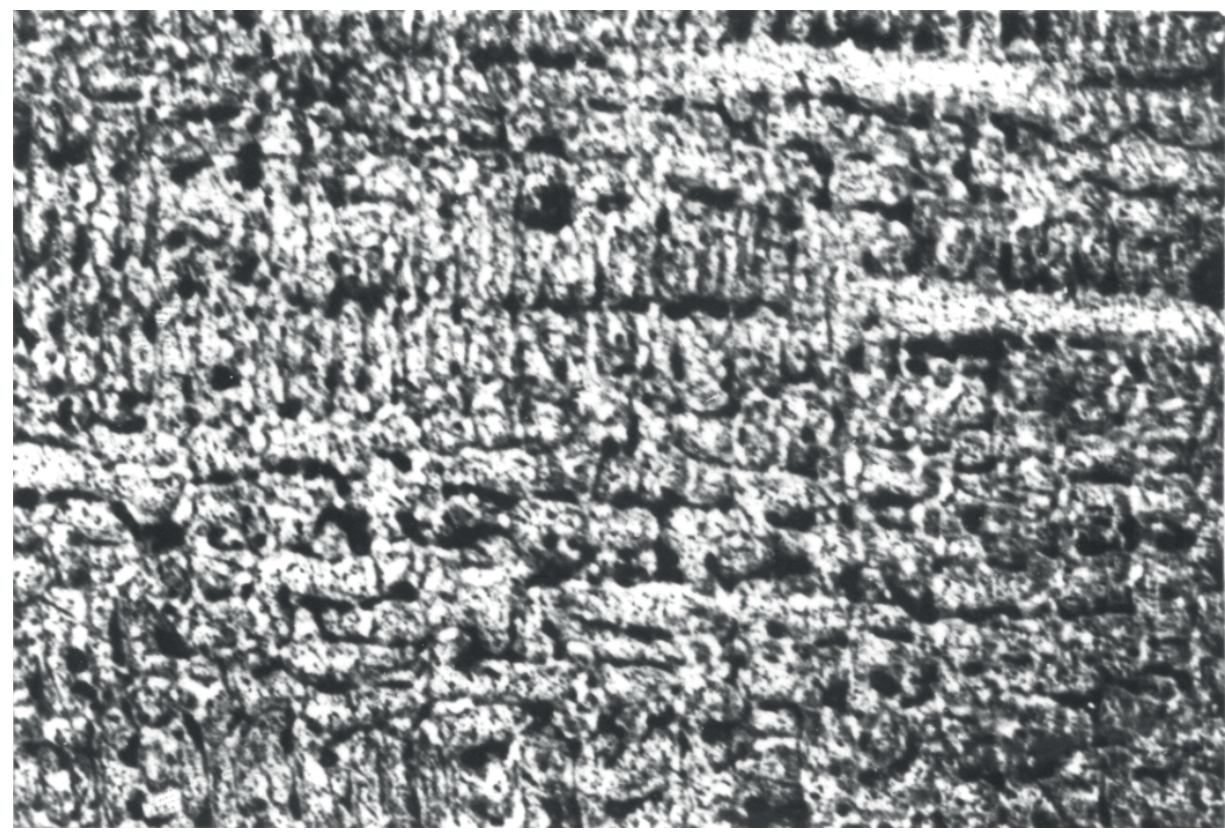

Fig. 7. Microstructure of polymetallic alloy from Series of Tests No. 1 (mag. 250x)

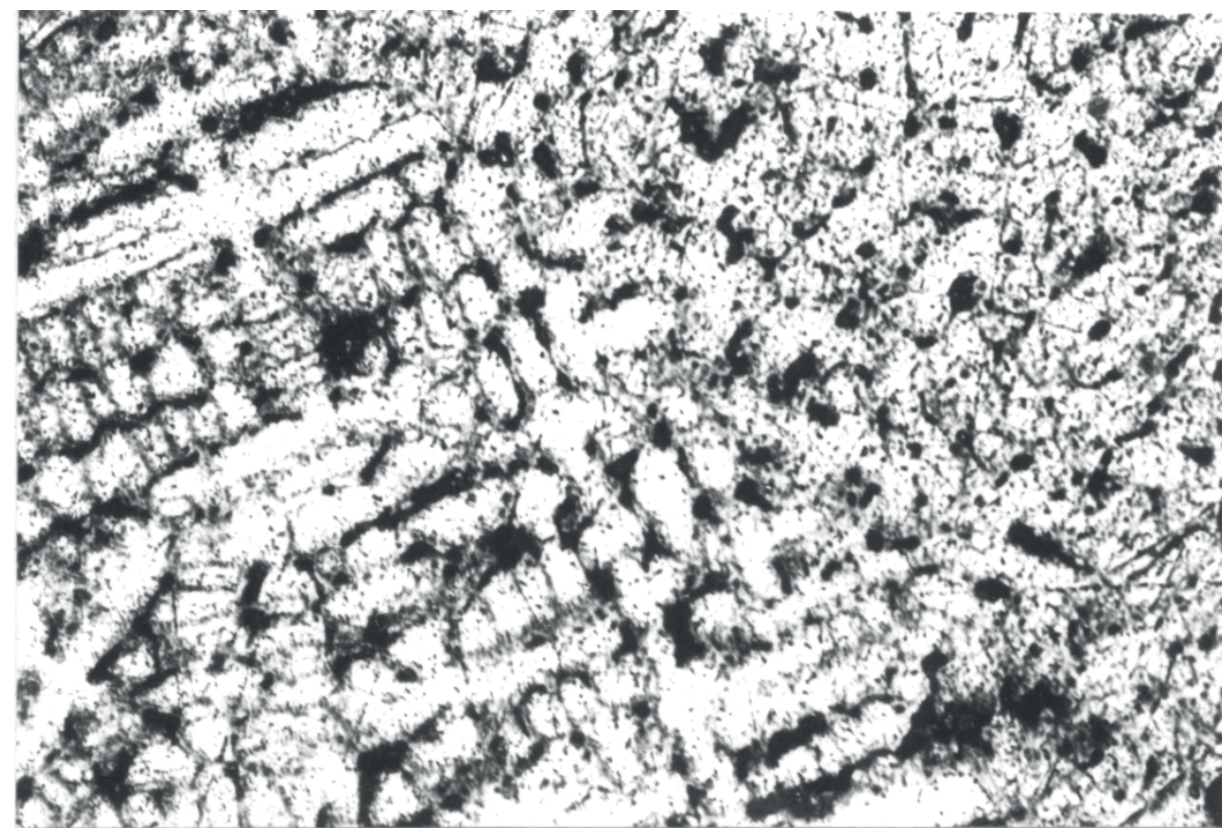

Fig. 8. Microstructure of polymetallic alloy from Series of Tests No. 2 (mag. 250x) 


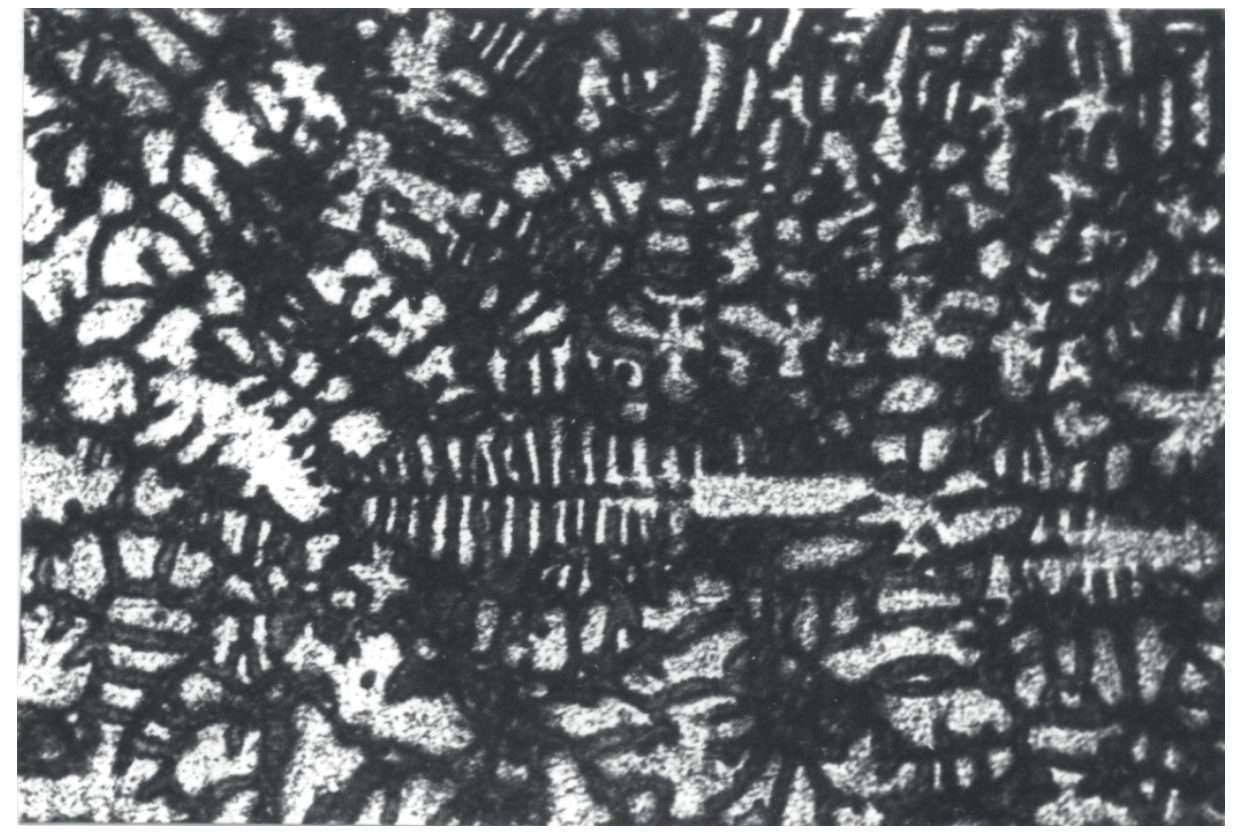

Fig. 9. Microstructure of polymetallic alloy from Series of Tests No. 3 (mag. 250x)

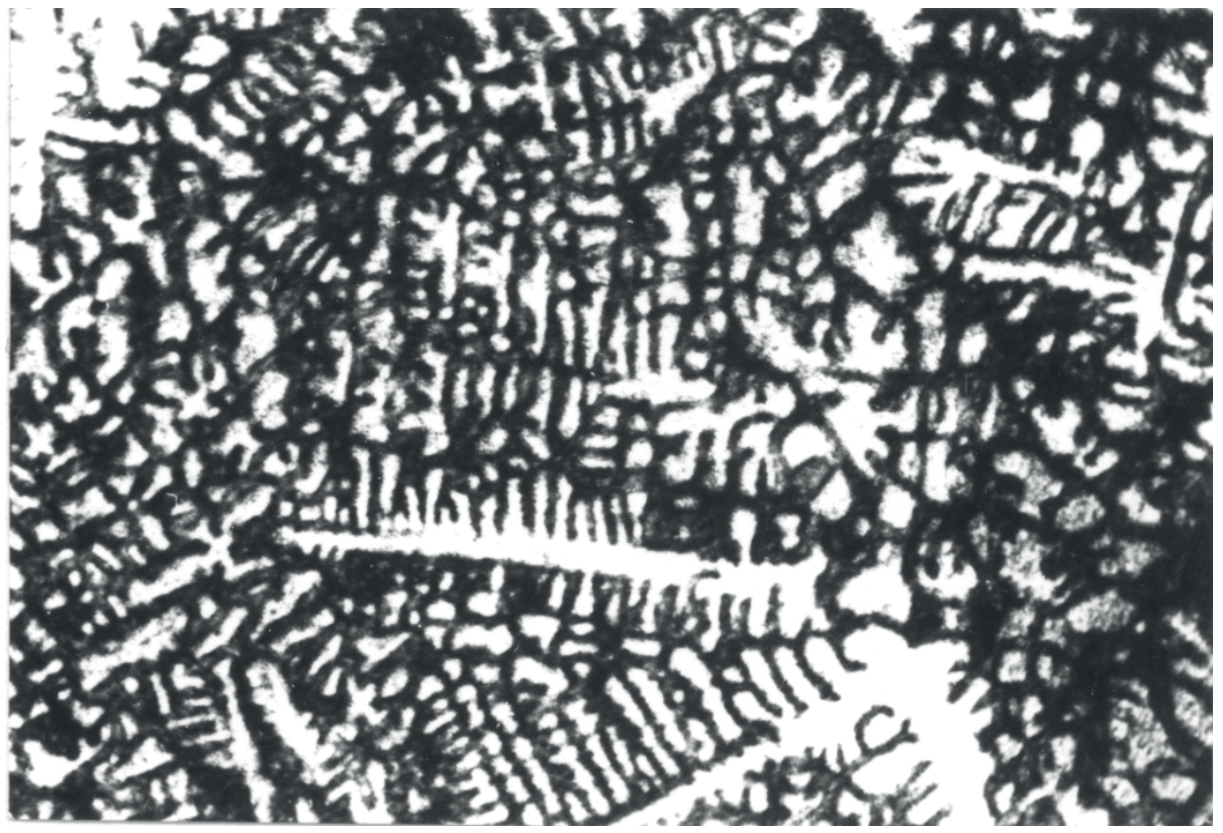

Fig. 10. Microstructure of polymetallic alloy from Series of Tests No. 4 (mag. 250X) 


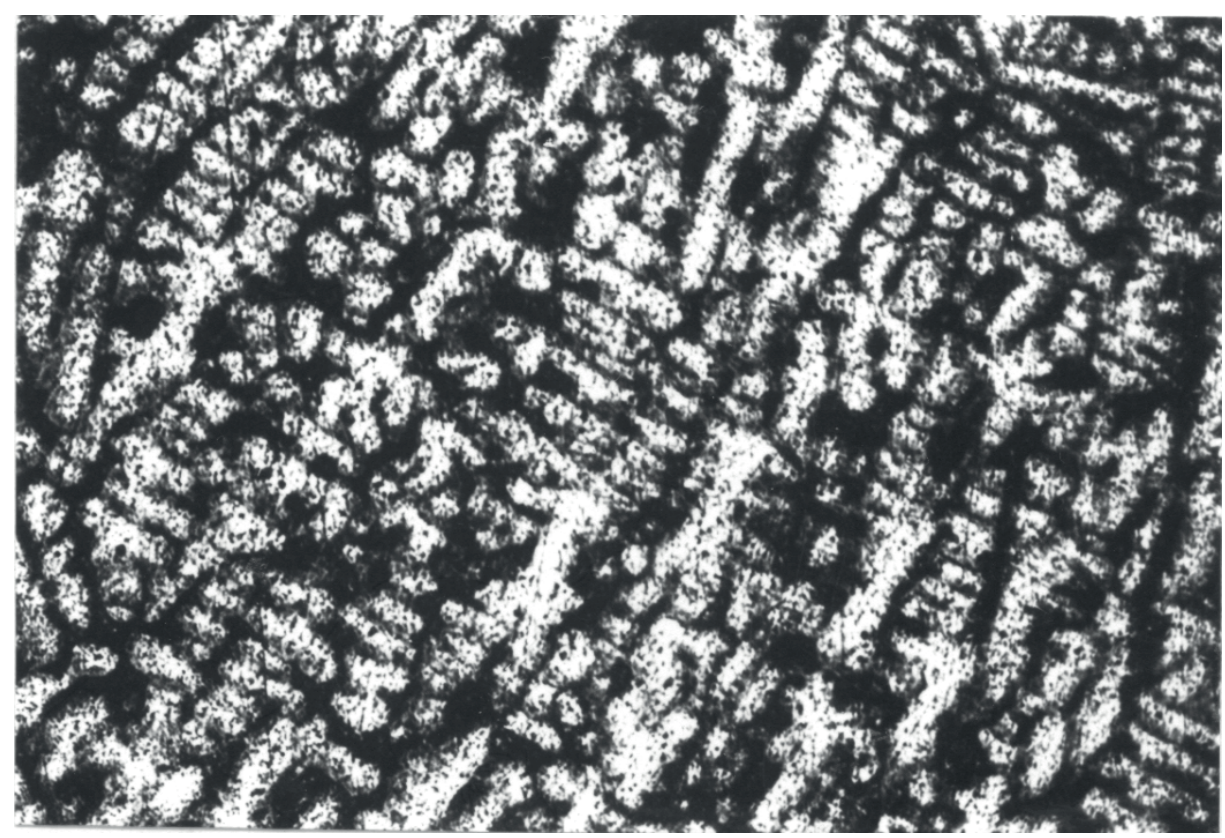

Fig. 11. Microstructure of polymetallic alloy from Series of Tests No. 5 (mag. 250×)

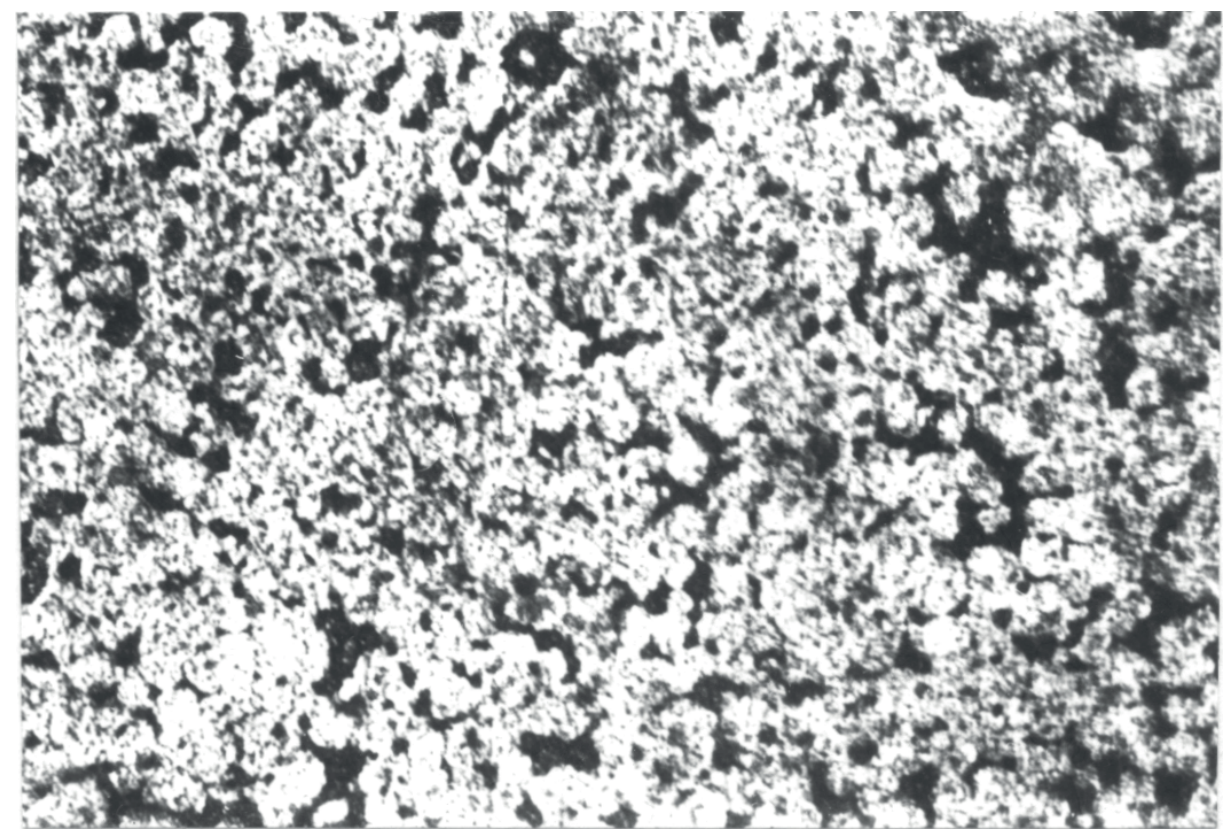

Fig. 12. Microstructure of polymetallic alloy from Series of Tests No. 6 (mag. 250x) 


\section{Analysis of test results}

The analysis of the obtained results of our research on the decomposition of slag from the slurry process (Tabs. 3-8 and Figs. 7-12) justifies the observations presented below.

A significant reduction in the copper content in the slag occurs during the first hour of the dispensing process. During this period, the highest efficiency of the dispensing process is observed, which results from the high reduction activity of the reducing mixture. The copper content in the slag reaches less than $3 \%$. A further reduction of the copper content to below $0.3 \%$ in the slag occurs only after four hours.

The better effect of slagging provides a better blending effect with $80 \%$ carbide, $15 \% \mathrm{Na}_{2} \mathrm{CO}_{3}$, and $5 \% \mathrm{CaF}_{2}$, as it provides a copper content reduction of up to $0.27 \% \mathrm{Cu}$ when adding $2.5 \%$ as related to the slag mass. Increasing the amount of the added mixture to $4 \%$ did not improve the effect of the slagging change.

The microstructure of the polymetallic alloy (Figs. 7-12) changes as the share of lead in the alloy increases. With a lead content of $10.8-11.81 \% \mathrm{~Pb}$ (Figs. 7 and 8 ), the alloy structure is characterized by large dendrites of a solution of solid alloy components in the copper. With a lead content of 12.11-13.29\% (Figs. 9 and 10), the dendrite of a solid solution of a smaller size can be seen in the alloy structure. A further increase of $14.21-16.48 \% \mathrm{~Pb}$ in the lead content in the alloy resulted in a change of the solid solution form from clearly shaped dendrites to irregular crystallites surrounded by a large amount of the lead phase. The observed changes in the structure of the polymetallic alloy were also caused by an increased share of iron $(0.08-0.39 \%)$ as well as the presence of other alloy components.

\section{Conclusions}

The tests showed the high reduction efficiency of the reductive mixture that was used. As a result of its impact on the slag from the slurry process, the copper content in the slag was reduced from $13.62 \%$ to $0.27 \%$. The best effect of dispersing the slag suspension occurred with a reducing agent that was composed of $80 \%$ carbide, $15 \% \mathrm{Na}_{2} \mathrm{CO}_{3}$, and $5 \% \mathrm{CaF}_{2}$. The addition of a reducing mixture as related to the weight of the slag to be subjected to pessiming may be limited to $2.5 \%$. The slagging of the suspension slag product is a polymetallic alloy containing $78.55-84.94 \%$ copper, $10.8-16.48 \%$ lead, and $0.08-0.39 \%$ iron.

\section{References}

[1] Monografia KGHM Polska Miedź SA, Piestrzyński A. et al. (red.) ,„Cuprum”, Wrocław 1996

[2] Karwan T.: Polskie złoto: profesor Tadeusz Karwan o miedzi. Wydawnictwo „Druk-Ar”, Głogów 2012 
[3] Romankiewicz F.: Wpływ łuku elektrycznego na proces rafinowania miedzi karbidem. [In:] Materiały IV Ogólnopolskiej Konferencji Nauka-Technologie "Tendencje rozwojowe w technologii maszyn". Wydawnictwo Uczelniane Wyższej Szkoły Inżynierskiej w Zielonej Górze, Zielona Góra 1979, 33-45

[4] Bydałek A., Jocz Z., Romankiewicz F.: Wpływ procesów przebiegających w powłokach żużlowych na własności brązów topionych ze złomów. [In:] III Międzynarodowa Konferencja Odlewnictwa Metali Nieżelaznych, Kraków 1976, 37-51

[5] Bydałek A., Brzózka M.: Stapianie karbidu z żużlami metalurgicznymi. [In:] Materiały IV Ogólnopolskiej Konferencji Nauka-Technologie „Tendencje rozwojowe w technologii maszyn”. Wydawnictwo Uczelniane Wyższej Szkoły Inżynierskiej w Zielonej Górze, Zielona Góra 1979, 7-12

[6] Bydałek A.: Aktywne związki wapnia w metalurgii metali nieżelaznych, Monografia nr 22. Wyd. WSI w Zielonej Górze, Zielona Góra 1983 